\title{
Afro-descendants and social stratification in Mexico. New evidence from the 2015 Intercensal Survey*
}

\section{Afrodescendientes y estratificación social en México. Nueva evidencia con datos de la Encuesta Intercensal 2015}

\author{
Eduardo Torre-Cantalapiedra y Gabriela Sánchez-Soto \\ El Colegio de la Frontera Norte, México/Centro de Estudios \\ México-Americanos de la Universidad de Houston, Estados Unidos
}

Abstract

The 2015 Intercensal Survey marks the first time African descent self-identification was included on a nationally representative survey in Mexico. Before that, there were no nation-wide official counts of the Afro-Mexican population. In this paper we use ordinal logistic regression models to examine the effect of being Afro-descendant on the educational and occupational status of Mexicans. Contrary to expectations, our results show that, at the national level, there is no evidence that the self-identified Afro-Mexican population has a lower socioeconomic status than other Mexicans. This contradictory result may be attributed to a higher likelihood of Afro-descendant self-identification among more educated people, and lower among the most disadvantaged, particularly in areas where Afro-Mexicans are less represented.

Keywords: Educational status; occupational status; social stratification; race and ethnicity; ethnic-racial self-identification.

\section{Resumen}

La Encuesta Intercensal de 2015 es la primera encuesta representativa a nivel nacional en la que se incluyó una pregunta sobre autoidentificación afrodescendiente. Antes de eso, no había recuentos oficiales a nivel nacional de la población afromexicana. En este artículo utilizamos modelos de regresión logística ordinal para examinar el efecto de ser afrodescendiente en el nivel educativo y estatus laboral de los mexicanos. Contrariamente a lo esperado, nuestros resultados muestran que, a nivel nacional, no hay evidencia de que la población que se autoidentifica como afromexicana tenga un estatus socioeconómico más bajo que otros mexicanos. Este resultado inesperado puede deberse a una mayor propensión a autoidentificarse como afrodescendiente entre las personas más educadas y menor entre las más desfavorecidas, particularmente en áreas donde los afromexicanos están menos representados.

Palabras clave: Estatus educativo; estatus ocupacional; estratificación social; raza y etnicidad; autoidentificación étnico-racial.

* This article was developed from presentations at the 2016 Annual Meeting of the Population Association of America, and the XIII National Meeting of Demographic research in Mexico organized in 2016 by the Mexican Demographic Society. 


\section{INTRODUCTION}

F or the first time in the history of Mexican statistics, the 2015 Intercensal Survey included a question that aims to identify the Afro-descendant population in the country. Being able to estimate the size of the Mexican population of African origin will bring increased visibility of this population which, up to now, lacked any official count. The count also helps Mexicans of African descent achieve statistical recognition and improves our ability to learn more about their socio-economic, demographic, and family characteristics. This could, in turn, lead to greater legal recognition and the development of specific public policies at different governmental levels in order to attend to their specific needs and improve their living conditions. ${ }^{1}$

Despite the work that anthropologists and historians have done in this field for a few decades² (Aguirre, 1946, 1972; Sue 2013; Hoffman and Rinaudo, 2014), the previously documented exclusion and disadvantage experienced by the Afro-descendant population in Mexico has not been sufficiently attended to, particularly in the Demographic literature. Up until now, there was no systematic and representative source of data to make national-level estimations on the situation of the Afro-Mexican population. This lack of data translates into an inability to understand whether the socioeconomic disparities in the population, especially among Afro-descendant or indigenous Mexicans, are a result of human capital composition or of a process of ethno-racial discrimination (Nopo et al., 2010). Without proper data or measures available, it is difficult to determine what explains differences in social status. Stratification arguments rely on attributing differences in labor market achievement to differences in human capital attainment, and on human capital attainment being itself associated to processes of exclusion within the educational system (see, for instance, Telles and Ortiz, 2011). Further, differences in human capital may be attributed to the higher or lower concentration of Afro-descendant population in the most disadvantaged areas of the country or to factors that may be related to economic exclusion and not only to racial discrimination. With the avai-

1 As it has happened in other countries in the region, such as Brazil, which today has affirmative action policies (Telles and Paixão, 2013).

2 Velázquez and Hoffmann (2007) point out that a vast literature on Afro-descendants in Mexico has been produced mainly within History and Anthropology, however additional research is still needed on this population. 
lability of race identification measures, these arguments can be tested in a more systematic way.

The aim of this study is to examine where the Afro-descendant population is located within the Mexican social stratification system based on the newly added Afro-descent self-identification question available in the 2015 Intercensal Survey. We focus on two main research questions: What is the size and sociodemographic characteristics of the self-identified Afro-descendant population in Mexico? And, what are the determinants of the educational and occupational status of Afro-Mexicans compared to other ethno-racial groups in Mexico? To answer these questions, we first present a description of the size, characteristics, and geographic distribution of the Afro-descendant population in Mexico. Second, we compare the educational attainment and occupational status of those self-identified as Afro-descendant to indigenous Mexicans and to the rest of the population. Third, we estimate two ordinal logistic regression models to examine how Afro-descendant self-identification is associated with attaining higher levels of education and occupation net of other characteristics.

We expect that our exploratory analysis will provide a snapshot of the composition and socioeconomic circumstances of the Afro-Mexican population and by contrasting it with the indigenous population - for which research is extensive-, we will obtain a clearer idea of the stratification system in Mexico. With this being a first attempt at defining this population, we hope that by exploring the characteristics of those identified as Afro-descendant we will gauge the reach of racial identity and the implications that auto-recognition has for the visibility and potential mobilization of Mexicans of African origin.

\section{LITERATURE REVIEW}

\section{Previous research on Afro-descendants in Mexico}

According to Velázquez and Iturralde (2012), the places where the contemporary Afro-descendant population are concentrated are the Costa Chica region in the states of Guerrero and Oaxaca - which is located in the coastal plains of the Pacific, from the south of Acapulco to Huatulcothe state of Veracruz, the Costa Grande region - which includes the area between the port of Acapulco to Zihuatanejo in Guerrero- - and the town of El Nacimiento, in Muzquiz, Coahuila where the Mascogo group is located. Numerous anthropological studies have been conducted in these specific regions and they provide the evidence available on this population 
with regard to a diversity of topics. For example, they have studied black and Afro-descendant identity (Lewis 2000; Hoffmann 2008; Sue 2013; Gil 2013 , to name some of the latest research) or racial mixing (Sue 2013; Hoffmann and Rianudo, 2014). Moreover, there are many historical studies about these regions (see Velázquez and Iturralde, 2012).

With regard to the life conditions of Afro-descendants in Mexico, the literature has found that evidence of the precarious situation of the Black population in Mexico relates to areas of the country where the African descent population historically settled, and where there is still a higher concentration of Blacks (e.g. black communities). Velázquez and Iturralde (2012) have found evidence that in regions of the country where these populations are more visible, like in the states of Guerrero, Oaxaca, Tabasco and Veracruz, they are likely to experience higher rates of economic and social marginalization. This marginalization is reflected in their more limited access to basic infrastructure, education and health services, as well as other political, social and cultural rights. Flores and Lézé (2007) find lags in education and economic status among Afro-descendants in ten Afro-Mexican settlements in the states of Oaxaca, Guerrero (Costa Chica), and Veracruz. At the same time, it has been noted that the Afro-descendant population in Mexico faces many different types of discrimination, such as, racial, formal, substantive, direct, multiple, and structural (Conapred and Movimiento Nacional por la Diversidad Cultural de México, 2011).

Despite plenty of evidence to support the need to create specific policies to include Afro-Mexican populations, in reality, there have been few measures directed at this population - one exception being their acknowledgement in statistical data collection (Torre Cantalapiedra, 2017). The lack of legal recognition of Afro-Mexicans is clear, and by not being legally recognized as a minority population, they are also excluded from the political agenda. In contrast, indigenous populations and communities are recognized in the Mexican Constitution, while Afro-Mexicans are only given legal recognition in the Political Constitution of the State of Oaxaca. By not being acknowledged in the same way as indigenous people, Afro-descendants do not have the support from governmental programs aimed at improving their living conditions (Conapred and Movimiento Nacional por la Diversidad Cultural de México, 2011). However, this lack of recognition in the law does not mean that Afro-Mexicans cannot gain access to government support, as they can access other welfare programs which, though not directly focused on the Afro-descendant populations, are directed to those living in poverty (CEPAL, 2017). As a result, the pro- 
portion of Afro-descendant households that receive welfare income from the government is 1.8 percent higher than the national median which is at 65.5 percent (INEGI, 2017).

Although our review shows there is abundant literature on the Afro-descendant population, we still know little about the place this population occupies within the Mexican stratification system, particularly from specific disciplinary areas, such as Social Demography. In a seminal work by Aguirre $(1946,1972)$ various demographic sources are used, but for decades, the lack of quantitative data identifying African descent prevented the demographic study of race/ethnicity in Mexico, as in much of Latin America. More recently, other research has focused understanding the relationship between stratification and race/ethnicity in Mexico (Villarreal, 2012; Telles, 2014); however, national-level analyses on Afro-Mexicans are still scarce.

\section{Racial and ethnic stratification in Mexico}

In recent years, new sources of data have allowed Latin American demographers to examine stratification and social inequalities associated to ethnic and racial issues (Villarreal, 2010; Flores and Telles, 2012; Martínez et al., 2014; Telles et al., 2015). This research gave primacy to the external determination of skin color as an element of classification (Torre Cantalapiedra, 2018), since they consider that skin pigmentation is a fundamental element of the social determination of race that reflects how people are located in the color-race hierarchy and how they are treated by society (Sue, 2013). Therefore, skin pigmentation, and more generally, ethno-racial differences are key elements to the study of social stratification in Mexican society.

Differences in the level of education and occupation have been frequently used in Mexico to account for social stratification and inequality among different ethnic and racial groups (Villarreal, 2010; Flores and Telles, 2012; Martinez et al., 2014). Using the Mexico 2006 Panel Study, Villarreal (2010) found that people with darker skin tone have the lowest socioeconomic status, followed by those with medium skin color, even after controlling for several individual characteristics of the respondents.

Flores and Telles (2012) propose to disentangle issues of race, ethnicity and class in terms of their implications for the Mexican social stratification system; using a nationally representative survey conducted in several countries, including Mexico, the Latin American Public Opinion Project (LAPOP 2010), which allows to analyze the socioeconomic status of peo- 
ple separating what pertains to race and ethnicity from class. While Flores and Telles agree with Villarreal (2010) that skin color is a good predictor of socioeconomic status (SES), they believe skin color affects socioeconomic status before individuals enter the labor market, because the relevant determinants of SES are the education and occupation of the individual's parents.

For their part, Martinez et al. (2014) analyzed educational attainment by race and ethnicity using data from the Project on Ethnicity and Race in Latin America (PERLA). They note that, when academic performance is analyzed using categories of ethno-racial self-identification (indigenous, whites, and mestizos ${ }^{3}$ ), mestizos have higher levels of education compared to the other groups; whereas when the classification based on a skin color palette, darker skin is consistently associated with lower educational levels, even after controlling for different ethno-racial categories. Although this study uses ethnic and racial identification categories to analyze social stratification, the sample size of the PERLA's surveys in Mexico did not allow to include the Afro-descendant population in the analysis.

From our review of previous research, we would like highlight two main ideas:

1. The current existence of discrimination against Afro-Mexicans that centers, among other things, on access to education and occupational status has historical roots and not exclusively racial ones. This has been made evident in existing anthropological and historical research, specifically in the regions of the country where these populations are more concentrated and visible (for more on this see the work by Flores and Lézé, 2007). Although this history of discrimination may not affect all Afro-descendants in Mexico, it would be reflected in the aggregate indicators for this population.

2. Because of the skin color of the African-origin population, Afro-descendant/Black Mexicans are likely to have a darker skin color than other population groups and to possess phenotypic traits that differentiate them from the rest of the population, as a result, they would be more likely to suffer racial discrimination in schools and in the workplace. Several studies have demonstrated this disparity (see for example Villarreal, 2010; Flores and Telles, 2012; Martínez et al., 2014; Arceo-Gomez and Campos-Vazquez, 2014; Telles et al., 2015). Although this assertion needs to be tested in future research, there are

3 The term mestizo refers to the population of mixed European and Indigenous ancestry in Mexico where they make the majority of the population. 
certain elements that make us expect that it is correct: i) Martínez et al. (2014) found that skin tone is consistently associated with self-ascription of people to certain ethnic and racial categories in Mexico; ii) Afro-descendants (blacks/pretos) in Brazil and Colombia, have been characterized as people with darker skin tones that have suffered racist and segregationist practices (Anton and del Popolo, 2009; Telles, 2014); and iii) the use of the term "Black," (negro in Spanish) even if it is not with the intention of identifying Afro-descendants, may have as a consequence the inclusion of those with darker skin tones, and the exclusion of people with lighter skin. This could result in an overestimation of the Afro-descendant population, creating potential bias in the self-identification question versus the external determination of skin color; notwithstanding the already concerning potential for underestimation of the Afro-descendant population due to lack of awareness or racial consciousness, and lighter skin Afro-descendants not identifying as such.

\section{Objective and hypotheses}

Our objective is to estimate the situation of self-identified Afro-descendants in the Mexican social stratification system. The self-identification measure is less objective than an external determination of skin color that previous research has used to observe racial stratification in Mexico. However, self-identification has been considered a good approximation for the measurement of social indicators that reflect living conditions and social inequities (Schkolnik, 2009). In this case, we consider it is useful to observe the possible disadvantages in the lives of Mexicans who identify as Afro-descendants, including their sociodemographic characteristics, and where they are situated within the Mexican social stratification system.

As it is the first time that a measure on African-descent is available on a large-scale nationally representative data, we are able to provide new understanding of the status of the black population in Mexico, although this choice of measurement is not free from limitations. In addition, one of the most important objectives of including the question on Afro-descendants in the Intercensal survey was precisely to allow the study of the socioeconomic conditions of Afro-Mexicans, to inform the development of public policies targeting this population, and to address existing social inequality. As described above, previous anthropological and demographic research leads us to expect that the Afro-descendant population would be more disadvantaged than the rest of the population in terms of both access 
to education and occupational status. As such, they would be more likely to have lower levels of schooling and to be in lower status occupations than the rest of the population. In contrast to existing research focusing only on limited geographies, the nationally representative sample of the Intercensal Survey allows us to identify whether the disparities observed in Afro-descendant communities remain at the national level.

\section{Data AND MEASUREMENT}

\section{Race and ethnicity measures}

We use the 2015 Mexican Intercensal Survey conducted by the National Institute for Statistics and Geography (INEGI, for its acronym in Spanish). The purpose of the Intercensal Survey is to generate statistical information on the size, composition and distribution of population in the country, as well as to provide indicators of its main characteristics. To prepare the final questionnaire INEGI considers the relevance of the survey questions for the definition of public policy at different levels of government (INEGI, 2015). The great advantage of this survey is its large sample size, and that small-size municipalities and municipalities with lower levels of human development are fully covered for their relevance to policy making, which allows to produce more precise estimates as it enables analyses of "small populations" and the assessment of differences by region. The coverage of the data collection enables us to conduct a more accurate analysis of a relatively small population, like Afro-descendants in México.

The survey includes two questions on racial/ethnic self-identification: Indigenous and Afro-descendant. Although the question on indigenous self-identification was similar in the censuses of 2000 and 2010, this is the first time it is presented with the current phrasing and response options. As mentioned above, this is also the first time a question on Afro-descendant identity is included. The question on Afro-descent identification asks each household member whether according to their culture, history and traditions, the individual self-identified as black, Afro-Mexican or Afro-descendant (see Table 1 for the exact text of the question). Most of the time, though, the interview is conducted with one member of household, generally the head of household (jefe de hogar), so responses for the rest of the family may rely on this one member's choice. Thus, even though it is described as a "self-identification question", most of the information co- 
rresponds other's identification of the household member. ${ }^{4}$ Because of this, we think of this population as "population considered Afro-descendant" which includes both people who identified themselves Afro-descendant and people who were identified as Afro-descendant by other member of the household. ${ }^{5}$ But for the sake of simplicity, we refer to them as "self-identified" throughout. Responses on indigenous and Afro-descent identification are not mutually exclusive, so many respondents may be identified as both (Table 1).

Table 1: Question about Afro-descendant self-identification in the 2015 Intercensal Survey*

Afro-Descendants

According to her/his culture, history and traditions, does (NAME) considers her/himself Black, that is, Afro-Mexican or Afro-descendant?

\section{Circle One}

Yes 1

Yes, in part 2

No 3

Do not know 8

* Original text of the question in Spanish: "De acuerdo con su cultura, historia y tradiciones, ¿(NOMBRE) se considera negra(o), es decir, afromexicana(o), es decir, afromexicana(o) o afrodescendiente?"

Source: 2015b, Intercensal Survey, Mexico, INEGI.

The inclusion of these two questions in the Intercensal Count gives statistical recognition to Afro-descent self-identification, helps grasp the complexity of the phenomenon of identities in Mexico, and enables a more constructive approach to addressing ethnic identity. The self-identification approach is appropriate in this context because it allows the respondent to decide which identities he or she relates to, which is useful given the

4 The possible answers to the question are "yes," "yes, in part," "no," and "does not know." The interviewer does not read out the answer options to the respondent, they rather record an appropriate response according to the response elicited. When the respondent mentions that they are Afro-Mexican for instance, "only on their father's side" or "only in part," the interviewer selects the "yes, in part" response. If the respondent does not know the identification of other members of the household, the interviewer marks the "do not know" option. Interviewers are also instructed to explain the meaning of the term Afro-Mexican to make sure the respondent understands its meaning.

5 This excludes the indigenous population, because it has long been considered to be in the most precarious conditions. Sandoval and Fernandez (2005, p. 26; authors' translation) note that "the serious socio-demographical lags in which indigenous groups live and their de facto exclusion with respect to multiple aspects of the 'rule of law' still represent the main debt of the country's public policy." 
intensity of existing interethnic relations. In the survey we see that many people identified themselves both indigenous and Afro-descendant. Future research should further explore what is behind this intersection of race/ ethnicity identification.

With regard to the question of indigenous self-identification, we can compare the results of the Intercensal Survey with results from the censuses in 2000 and 2010, in which 6.6 and 14.8 percent of the population of Mexico considered themselves indigenous. In 2015, the percentage rose to 21.5 percent, and if we add those who considered themselves indigenous in part ( 1.5 percent) the total would be approximately 23 percent of the population. An important part of the variation across years may be due to differences in the phrasing of the questions and the response options (Martínez et al., 2014). ${ }^{6}$ But while the questions in 2000 and 2010 were very different, they were not so different between 2010 and 2015. In addition, the response options "do not know" and "yes, in part", added in 2015, would only decrease the percentage of "yes". So, what could explain the almost seven points increase in affirmative responses obtained in 2015 in comparison the census five years ago? Especially given the fact that the number of indigenous language speakers remained virtually unchanged in the same period. This fluidity may be related to the multidimensionality and the different meanings of ethnic and racial identity in Mexico (Martinez et al., 2014). More work is needed to understand these changes and whether they are related to greater ethnic awareness.

Consequently, a fundamental question that must be resolved first is: to what extent is the question about Afro-descendant identification likely to have the same issues as the question of indigenous self-identification? Since Mexican nationalist ideologies emphasized mestizaje - the cultural and racial mixing of the indigenous and Spanish populations-, and indigenous ancestors - including their elevation as the original inhabitants of the Mexican nation and their importance in Mexican culture-, a large part of the population in Mexico may have a propensity to recognize themselves as indigenous, according to current trends. However, it is less likely that the question on Afro-descendant self-identification would show the same variation as indigenous self-identification, as this ethno-racial category re-

6 In 2015 the question text said: "According to his/her culture, does (NAME) considers themselves indigenous?" the Interviewer must then select between the following answers: "Yes", "Yes, in part," "No" and "Do not know." In 2010 the question asked said: "According to the culture of [NAME], does he/she considers themselves indigenous?" with only two possible answers: "Yes" and "No." And in 2000 the question was: "Is (NAME) Náhuatl, Maya, Zapotec, Mixtec or from other indigenous group?" Possible answers were: "Yes" and "No." For more on this see Telles, 2014. 
fers to an invisible population that until now has been excluded from the notion of what is "Mexican," and which has plenty of negative stereotypes associated to it, thus we would not expect that the general population would identify as Afro descendant in the same way as they would identify with being indigenous.

Afro-descendant is a common expression to refer to the descendants of the African diaspora around the world since the World Conference against Racism, Racial Discrimination, Xenophobia and Related Intolerance held in Durban, South Africa in 2001 (Schkolnik, 2009; Popolo and Schkolnik, 2013). In the Glossary of the 2015 Intercensal Survey the definition of African descent pertains to

a person who descends from the Africans who arrived in Mexico during the colonial period to perform forced labor on farms, mills, mines, manufacture, or as traders, cooks, nurses, among other activities. It includes people who arrived in Mexico at other times of national history and who have African ancestors (INEGI, 2015a: 46; authors' translation).

The Intercensal Survey question on Afro-descent is the result of an arduous process that included various pilot tests, fieldwork, and public consultations on the different options to formulate the question. In addition, this question is a result of a debate involving various actors including federal- and state-level government, academics, civil society organizations, and other users of the data, all with diverse interests and degrees of influence over the final version of the question (Torre Cantalapiedra, 2017). The criterion adopted to identify the Afro-descendant population was self-identification. ${ }^{7}$ The final phrase used is "does (NAME) consider themselves...?" Furthermore, Afro-descent was framed as ethno-cultural self-identification as the text asks the respondent to identify "according to his/her culture, history and traditions."

Although the survey question uses the expression "black" (negro), it is clear that the intent of the question is to emphasize the ethnic aspect (Torre Cantalapiedra, 2017). Since a part of the Afro-descendant population recognize themselves as "blacks", the term was used in order to increase inclusion of this population. However, we cannot know to what extent the

\footnotetext{
One might question whether there can really be full self-identification with this methodology. The Intercensal Survey gives people the option to ascribe to a new identity category -afro-descendant-, however; the way the question is handled does not fully result in self-identification. The self-ascription options are limited by the survey and one person in the household answers for all of the household members. As a result, the results obtained for indigenous and Afro-Mexican self-identification are limited to the response categories available for each question and might differ depending on which household member is interviewed.
} 
respondents understand the question as a matter of racial identification or of skin color by using the term "black". This can be a confusing point because "negro," the Spanish word for "black" can be understood by some as a term identifying people with dark skin, regardless of African descent, while for others it might retain its African-origin connotation. At this point it is good to remember that some countries (Brazil and Colombia, for instance) opted directly for the use of such terms of racial and phenotypic recognition, with terms like preto (black) used in connection to skin color and phenotype, and not understood in ethnic terms. In this sense, some authors suggest that this may be the most appropriate choice of term to enhance the visibility of the Afro-descendent population. For instance, Urrea-Giraldo (2006) suggests that recognition of the racial or phenotypic dimension allows to observe the specific sociological phenomenon of rural and urban Colombian identity, which occurs through racial appearance or skin color.

In any case, since it is the first time a question of this type is included, the results shown in this paper should be understood as a first attempt to quantify and describe the Afro-descendant population at the national level, which for reasons related to self-identification and measurement may not capture the entire population of African descent. This potential undercount could occur for several reasons: i) because of a weak awareness of being Afro-descendant because racism and discrimination inhibit identification; ii) because of the ideology of mestizaje that equated being Mexican with being mestizo; or iii) because they identify themselves as something else more specific such as: afromestizo, brown (moreno), mascogo, ${ }^{8}$ etc. In this sense, among the people who answered "do not know," "unspecified," and the rest of the population who answered "no", there may be more people that could identify as Afro-descendant if they are asked again or if the question is asked differently. Conversely, the question might have included a population that for reasons of skin color or other considerations answered affirmatively, while not fitting into the aforementioned definition of African descent.

\section{Method}

In this paper we analyze the educational attainment and the occupational status of Afro-descendant population in Mexico, compared to the rest of the population and to indigenous Mexicans. We first describe and com-

8 "Mascogos are a group of Afro-descendant people in Mexico whose ancestors arrived in Mexican territory in the mid 19th Century. Their communities are located in the town of El Nacimiento in Múzquiz, Coahuila" (Velázquez and Iturralde 2012: 29). 
pare the educational attainment and occupational status of Mexicans by Afro-descendant and indigenous status. Then, we fit ordinal logistic regression models to estimate how being Afro-descendant is associated with different levels of educational attainment and occupational status, as well as to determine other sociodemographic determinants of education and occupation. ${ }^{9}$ The choice of ordinal logistic models instead of a nominal logistic regression model has the advantage of not having to impose a scale for the dependent variables (Villarreal, 2010). In contrast with the nominal logistic models, the ordinal logistic models prevent the loss of information on the ordering of outcomes (IDRE-UCLA 2015).

In the first set of ordinal logistic regression models the dependent variable is educational level attained, classified in seven categories and the main independent variable is Afro-descendant self-identification, the model also controls for sex, age, whether the respondent is an indigenous language speaker, indigenous self-identification, region, and whether the municipality of residence is rural (see Table 2).

Final model set 1:

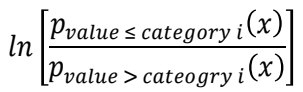

$$
\begin{aligned}
& =\alpha_{i}+\beta_{1} A F R O+\beta_{2} S E X++\beta_{3} A G E+\beta_{4} S P E A K+\beta_{5} I N D+\beta_{6} R E G \\
& +\beta_{7} \text { RURAL }
\end{aligned}
$$

The dependent variable can take the value of seven different categories of educational attainment which are: "no education to incomplete elementary," "elementary school," "middle school," "high school," "technical or commercial degree," "college degree," and "postgraduate degree." They are sorted from lowest to highest level of schooling.

Final model set 2:

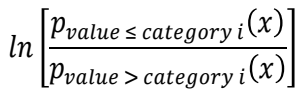

$$
\begin{aligned}
& =\alpha_{i}+\beta_{1} \text { AFRO }+\beta_{2} \text { SEX } \\
& +\beta_{3} A G E+\beta_{4} S P E A K+\beta_{5} E D U+\beta_{6} I N D+\beta_{7} R E G+\beta_{8} R U R A L
\end{aligned}
$$

\footnotetext{
9 Ordinal logistic regression models are used to model the relationship between a series of independent variables and an ordinal dependent variable. An ordinal dependent variable is coded in three or more categories that follow a natural order, for instance: low, medium, and higher level of formal education. Stata 13 was used to conduct the statistical analysis for this paper.
} 
Table 2: Operationalization of variables used in the analysis

\begin{tabular}{|c|c|}
\hline Variables & Operationalization \\
\hline Afro-descendant self-identification & $\begin{array}{l}\text { Equals } 1 \text { if respondent identified as } \\
\text { Afro-descendant, } 0 \text { otherwise }\end{array}$ \\
\hline Female & $\begin{array}{l}\text { Equals } 1 \text { if in respondent is female, } 0 \\
\text { otherwise }\end{array}$ \\
\hline Age & Age in years \\
\hline Respondent speaks an indigenous language & $\begin{array}{l}\text { Equals } 1 \text { if respondent speaks an indi- } \\
\text { genous language, } 0 \text { otherwise }\end{array}$ \\
\hline Indigenous self-identification & $\begin{array}{l}\text { Equals } 1 \text { if respondent self-identifies } \\
\text { as indigenous }\end{array}$ \\
\hline \multicolumn{2}{|l|}{ Educational attainment } \\
\hline None / Incomplete primary & 0 to 5 years of schooling (ref.) \\
\hline Complete primary & 6 to 8 years of schooling \\
\hline Complete secondary & 9 to 11 years of schooling \\
\hline High school & 12 to 13 years of schooling \\
\hline Technical or commercial studies & 14 to 15 years of schooling \\
\hline Bachelor's degree & 16 years of schooling \\
\hline Postgraduate & More than 16 years of schooling \\
\hline \multicolumn{2}{|l|}{ Region } \\
\hline Northwest & $\begin{array}{l}\text { Includes: Baja California, Baja } \\
\text { California Sur, Durango, Chihuahua, } \\
\text { Sinaloa, and Sonora (ref.) }\end{array}$ \\
\hline Northeast & $\begin{array}{l}\text { Coahuila, Nuevo León, and Tamau- } \\
\text { lipas }\end{array}$ \\
\hline West & $\begin{array}{l}\text { Colima, Jalisco, Michoacán and } \\
\text { Nayarit }\end{array}$ \\
\hline East & $\begin{array}{l}\text { Hidalgo, Puebla, Tlaxcala, and } \\
\text { Veracruz }\end{array}$ \\
\hline North Central & $\begin{array}{l}\text { Aguascalientes, Guanajuato, Quereta- } \\
\text { ro, and San Luis Potosí }\end{array}$ \\
\hline South Central & $\begin{array}{l}\text { Ciudad de México, México and } \\
\text { Morelos }\end{array}$ \\
\hline Southwest & Guerrero, Oaxaca, and Chiapas \\
\hline Southeast & $\begin{array}{l}\text { Campeche, Yucatán, Quintana Roo, } \\
\text { and Tabasco }\end{array}$ \\
\hline Rural municipality & $\begin{array}{l}\text { Equals } 1 \text { if municipality has less than } \\
2,500 \text { inhabitants }\end{array}$ \\
\hline
\end{tabular}

Source: 2015b, Intercensal Survey, Mexico, INEGI. 
In the second set of ordinal logistic models the dependent variable is occupational status classified in eight categories, the main independent variable is Afro-descendant self-identification, and the control variables included are: sex, age, education, speaks indigenous language, indigenous self-identification, region and rural.

There are different classifications of occupational status in Mexico according to the data used in each case (see, for example, Cortés and Escobar 2005; Zenteno and Solís 2006; Villarreal 2010). Given that the occupation variable in the 2015 Intercensal Survey is coded with a three-digits classification, we use a similar categorization of occupations as Solís (2002) which is composed of eight occupational categories..$^{10}$ In our case the eight categories of occupational status are: "workers in agriculture and livestock," "manual workers in services," "artisans and unskilled manual workers," "skilled manual workers," "sales employees and supervisors," "office workers and sales agents," "technical and professional office workers," and "managers and professionals." They are ordered from lowest to highest occupational status. Both of our analyses select only individuals ages 24 to 64 to include only adults who are most likely to have completed their education and those with a current occupation reported.

\section{Results}

\section{Characteristics and distribution of Afro-descendants in Mexico}

According to the data collected in the Intercensal Survey (INEGI 2015c: 77) the number of people who identified as Afro-descendants in Mexico is 1 ' 381,853 . If we add the 591,702 people who consider themselves part Afro-descendants, the total is almost two million (1.97 million, or 1.65 percent of the Mexican population). This number almost doubles the foreign-born population residing in Mexico (1'007,063 people or 0.84 percent of the population; INEGI 2015c: 17). The vast majority of Afro-descendants have Mexican nationality (over 98 percent). As noted above, this figure is likely to increase in future censuses, because an increased racial/ethnic consciousness could increase the number of Afro-descendant self-identifications.

Approximately three quarters of Afro-Mexicans ( 75.3 percent) are concentrated in just five states (Table 3). Mexico State has the highest number of Afro-Mexicans, 374,733 people, but it is not the state with the highest

10 These categories are: managers and professionals, skilled white-collar workers, clerical workers and sales agents, sales employees and control workers, skilled manual workers, unskilled manual workers, unskilled service workers, and farm workers. 
Afro-Mexican population density in Mexico. Guerrero occupies the first place, in that state seven out of every one hundred people self-identify as Afro-descendant and are Mexican nationals; Guerrero is followed by Oaxaca and Veracruz, and then Mexico State where six, four, and two out of every one hundred people are Afro-descendant, respectively. In the ranking, Mexico City is fifth in both absolute and relative terms.

Table 3: Absolute and relative size of the Mexican population self-identified as Afro-descendant by state

\begin{tabular}{lccc}
\hline State & $\mathrm{N}$ & State & $\%$ \\
\hline Mexico & 374,733 & Guerrero & 7.6 \\
Veracruz & 328,674 & Oaxaca & 6.0 \\
Guerrero & 267,527 & Veracruz & 4.1 \\
Oaxaca & 232,676 & Mexico & 2.3 \\
Mexico City & 204,430 & Mexico City & 2.3 \\
Rest of the country & 504,421 & Other states & 0.5 \\
\hline
\end{tabular}

Note: Figures include those who answered "yes" and "yes, in part" to the question on Afro-descent and who are Mexican nationals

Source: 2015b, Intercensal Survey, Mexico, INEGI.

Given the high concentration of Afro-descendants in some states, such as Guerrero, Oaxaca, and Veracruz, it makes sense that these areas of the country make up the majority of the previous anthropological, sociological and historical research. However, other places that have large populations of Afro-descendants in absolute terms such as the State of Mexico and Mexico City are not as well represented in previous research.

Finally, we want to stress that most people who identified as Afro-descendants in the 2015 Intercensal Survey, also identify as indigenous (about two thirds) (see Table 4). These figures seem to be associated to the importance of interethnic relations that exist between Afro-descendant and indigenous people in Mexico and peculiarities in the identity formation of this population. Especially as the regions of the country where Afro-Mexicans concentrate in are also areas with high proportions of indigenous population. Also, more than 178,000 people who responded affirmatively to the question about Afro-descendant identity also declared to speak some indigenous dialect or language (this means about 1 in 10 Afro-descendants). This complexity in identification is relevant, because the population speaking indigenous languages have been consistently characterized by their precarious life conditions and lower social status. In this sense, 
the ethno-racial indigenous and Afro-descendant categories should not be understood as mutually exclusive choices, but rather as relevant categories to understand more fully the identity of Mexicans.

Table 4: Absolute and relative size of the Afro-descendant Mexican population by type of affirmative response and by indigenous identification, Mexico 2015

According to their culture, does he/she consider him/herself indigenous?

\begin{tabular}{cccrrr} 
& & & Yes & Yes, in part & No \\
\hline \multirow{4}{*}{ Considered } & Yes & $\mathrm{N}$ & 890,179 & 21,300 & 430,697 \\
Afro-descendant & & $\%$ & 65.3 & 1.6 & 31.6 \\
& Yes, & $\mathrm{N}$ & 209,303 & 149,384 & 218,172 \\
& in part & $\%$ & 35.6 & 25.4 & 37.2
\end{tabular}

Do you speak any Indian language or dialect?

Yes

No

\begin{tabular}{|c|c|c|c|c|}
\hline \multirow{4}{*}{$\begin{array}{c}\text { Considered } \\
\text { Afro-descendant }\end{array}$} & \multirow{2}{*}{ Yes } & $\mathrm{N}$ & 128,083 & $1,173,806$ \\
\hline & & $\%$ & 9.4 & 86.1 \\
\hline & \multirow{2}{*}{$\begin{array}{l}\text { Yes, } \\
\text { in part }\end{array}$} & $\mathrm{N}$ & 50,825 & 511,945 \\
\hline & & $\%$ & 8.7 & 87.2 \\
\hline
\end{tabular}

Note: On the question of indigenous language speakers does not include children under 3 years of age.

Source: 2015b, Intercensal Survey, Mexico, INEGI.

\section{Patterns of schooling and occupation among Afro-Mexicans}

If we compare the educational distribution of the Afro-Mexican population against the rest of the population no significant differences are observed (Figure 1), in contrast if we compare indigenous language speakers - the group we expect to be more disadvantaged - to those who do not speak an indigenous language, the differences are significant (Figure 2). The percentage of indigenous language speakers who have less than a primary education is more than five times that of non-indigenous language speakers (approximately 18 percent versus 3.64 percent). 
Figure 1: Educational Attainment by Afro-Descendant Status, Ages 24 to 65, Mexico, 2015

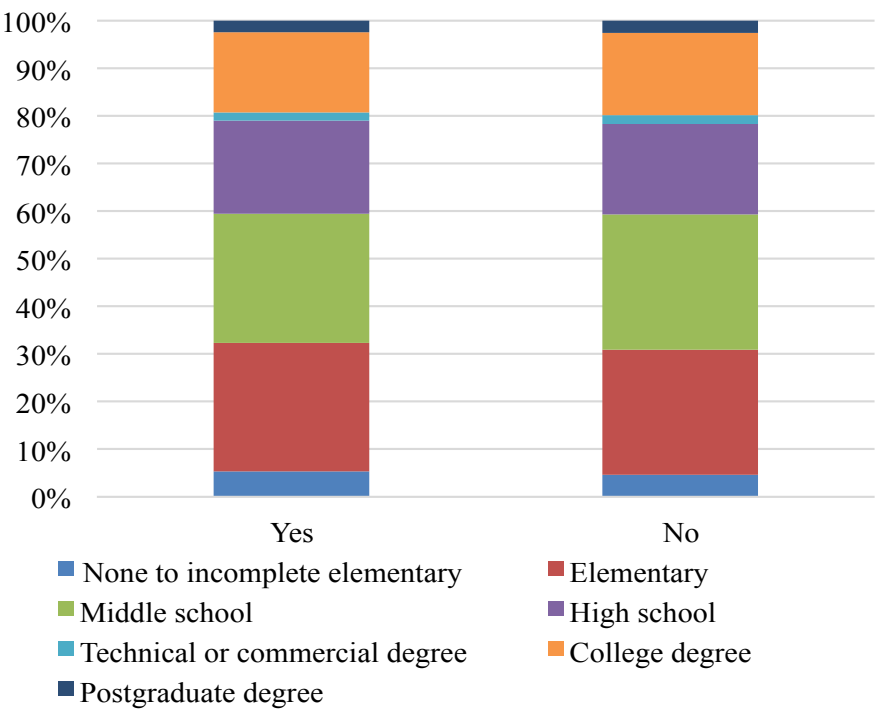

Source: 2015b, Intercensal Survey, Mexico.

Most of the indigenous language speakers have only attained an elementary school education (47.55), while there is more variation in the educational distribution of non-indigenous language speakers including higher proportions attaining middle and high school education, and almost one-fifth having a college degree. Among indigenous language speakers only 20.3 percent have a secondary school education and 7.6 percent high school education, and under five percent have a college-level education.

Just like with the level of schooling attained, when we compare the distribution of occupational status for the Afro-descendant population versus non Afro-descendants, we do not find significant differences (Figure $3)$. While when we compare indigenous language speakers versus those who are not, the differences are very substantial (Figure 4). Particularly, as expected, indigenous language speakers have a large overrepresentation in agricultural and livestock activities, which are at the lowest rung of the occupational classification. On the contrary, they have very little presence in the three highest occupational categories. 
Figure 2: Educational Attainment by Indigenous Language Speaker Status, Ages 24 to 64 , Mexico, 2015

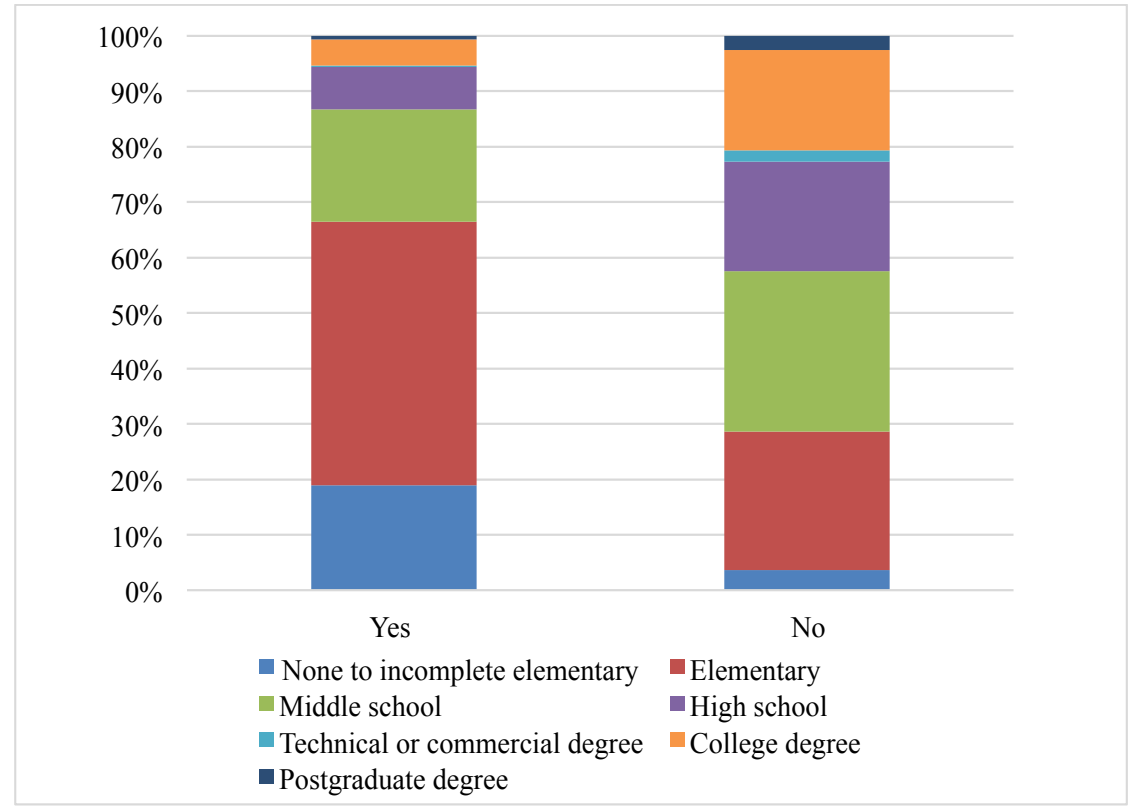

Source: 2015b, Intercensal Survey, Mexico.

In summary, we find that the black population is concentrated substantially in five states of Mexico, including three locations associated traditionally with Afro-descendants, and the most populous states in the nation, as are the State of Mexico and the Federal District. Analyzing the distribution of educational and occupational attainment for Afro-descendants versus non-Afro-descendants we do not find substantial differences between the two population groups, though we find that inequality persists for indigenous speaking groups. However, we still need to estimate whether these patterns remain when accounting for other factors in the multivariate analysis.

\section{Determinants of occupational and educational status}

To examine more accurately the association between Afro-descendant status and the attainment of education and occupational status, we estimated ordinal logistic regression models for Mexicans ages 24 to 64 . 
Figure 3: Occupational Attainment by Afro-Descendant Status, Ages 24 to 64, Mexico, 2015

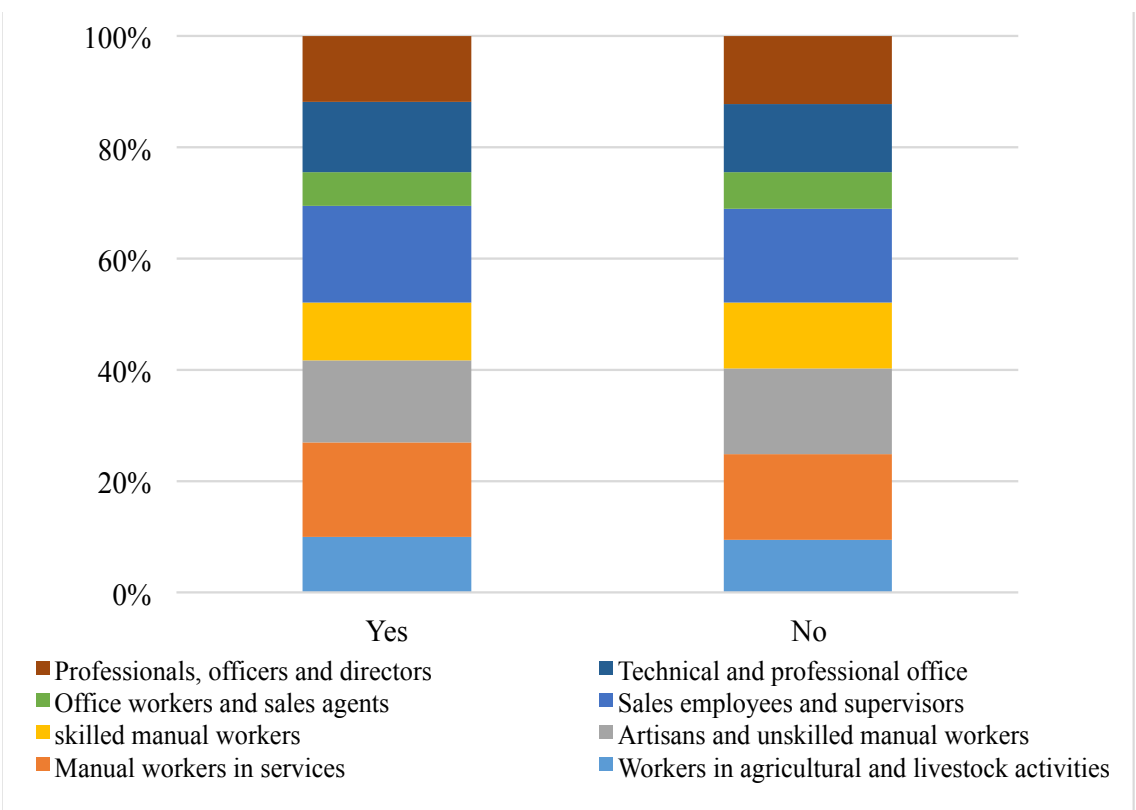

Source: 2015b, Intercensal Survey, Mexico.

Table 5 presents the models predicting educational attainment, Model 1 controls only for individual characteristics, Model 2 adds a control for region, Model 3 includes individual characteristics and a control for rural residence, Model 4 includes all variables, except for indigenous identification, and Model 5 is the full model.

Results from Model 1 show that those who identified as Afro-descendants or indigenous have lower levels of schooling. Though the effects follow the same direction and level of significance, speaking an indigenous language or identifying as indigenous has a negative effect of a larger magnitude than being Afro-descendant. Model 1 also shows women are more likely to have a higher level of education and that every year increase in age is related to lower levels of schooling. When we include controls for region of residence in Model 2, we can observe that the effects of indigenous status characteristics diminishes and the effect of being Afro-descendant reverses directions. 
Figure 4: Occupational Status by Indigenous Language Speaker Status, Ages 24 to 64 , Mexico, 2015

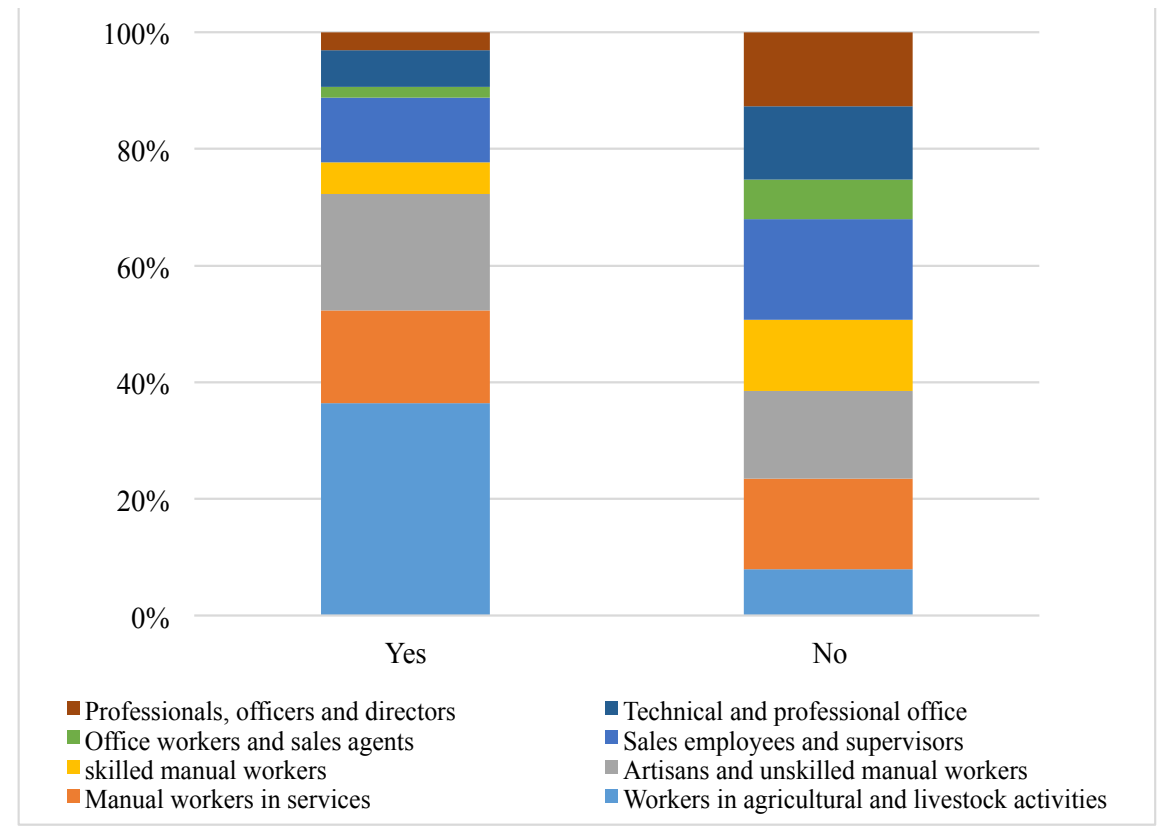

Source: 2015b, Intercensal Survey, Mexico.

Additionally, Model 2 shows that compared to those living in the Northwest, Northeast and Southeast residents have higher levels of schooling, whereas living in the remaining regions is associated to lower levels of education. Further, to test whether the contribution of geographic location is different when we account for rurality, Model 3 replaces the region variable for an indicator of rural status. Model 3 finds that living in a rural community is associated to lower levels of education. In this model the effects of indigenous status are further diminished, whereas Afro-Mexicans are still more likely to have higher levels of schooling.

To test whether accounting for indigenous status takes away from the effect of being Afro-Mexican, we estimate Model 4, where we remove the indigenous status indicators and include the other individual characteristics, as well as region and rural indicators. Results show a stronger positive effect of being Afro-descendant, and the effects of region and rural status retain the direction and significance observed in Models 2 and 3.

Lastly, Model 5, the full model, includes the full set of covariates. Overall, the consistent finding in these models is that once we control for re- 
gion and rural residence, self-identifying as Afro-descendant is positively associated to having higher levels of schooling. Albeit the effect is modest, in the full model (Model 5), people who considered themselves Afro-descendant have 7.8 percent increased odds $(\exp (0.075)-1)$ of attaining a higher educational level. Meanwhile, being a woman is also associated with higher levels of education compared to men, women have 23.6 percent higher odds of achieving a higher level of schooling. This is consistent with recent trends of women attaining higher schooling than men in Mexico.

Table 5: Ordered logistic regression models predicting educational attainment ages 24 to 64, Mexico, 2015

\begin{tabular}{|c|c|c|c|c|c|}
\hline Indepe & Model 1 & Model 2 & Model 3 & Model 4 & Model 5 \\
\hline Afro-descendant & $\frac{-0.011 * * * *}{(0.004)}$ & $\begin{array}{l}0.097 \text { *** } \\
(0.003)\end{array}$ & $\begin{array}{l}0.008 * \\
(0.004)\end{array}$ & $\begin{array}{l}0.082 * * * \\
(0.004)\end{array}$ & $\begin{array}{l}0.075 \text { *** } \\
(0.004)\end{array}$ \\
\hline Female & $.197 * * *$ & $0.193 * * *$ & $0.217 * * *$ & $0.200 * * *$ & $0.212 * * *$ \\
\hline Age & $\begin{array}{l}(0.001) \\
-0.060) * * * \\
(0.000)\end{array}$ & $\begin{array}{l}(0.001) \\
-0.060 * * * \\
(0.000)\end{array}$ & $\begin{array}{l}(0.001) \\
-0.060 * * * \\
(0.000)\end{array}$ & $\begin{array}{l}(0.001) \\
-0.060 * * * \\
(0.000)\end{array}$ & $\begin{array}{l}(0.001) \\
-0.061) * * * \\
(0.000)\end{array}$ \\
\hline $\begin{array}{l}\text { Indigenous language } \\
\text { speaker }\end{array}$ & $-1.198 * * *$ & $-1.084 * * *$ & $-1.006 * * *$ & & $-0.950 * * *$ \\
\hline Indigenous & $\begin{array}{l}(0.002) \\
-0.421 * * * \\
(0.001)\end{array}$ & $\begin{array}{l}(0.002) \\
-0.348 * * * \\
(0.001)\end{array}$ & $\begin{array}{l}(0.002) \\
-0.325 * * * \\
(0.001)\end{array}$ & & $\begin{array}{l}(0.002) \\
-0.279 * * * \\
(0.001)\end{array}$ \\
\hline $\begin{array}{l}\text { Region (ref. Northwest) } \\
\text { Northeast }\end{array}$ & & $\begin{array}{l}0.144 * * * \\
(0.003)\end{array}$ & & $* * *$ & $* * *$ \\
\hline West & & $\begin{array}{l}-0.389 * * * \\
(0.002)\end{array}$ & & $\begin{array}{l}-0.406 * * * \\
(0.002)\end{array}$ & $\begin{array}{l}-0.408 * * * \\
(0.002)\end{array}$ \\
\hline East & & $\begin{array}{l}-0.347 * * * \\
(0.002)\end{array}$ & & $\begin{array}{l}-0.418 * * * \\
(0.002)\end{array}$ & $\begin{array}{l}-0.279 * * * \\
(0.002)\end{array}$ \\
\hline North central & & $-0.326 * * *$ & & $-0.230 * * *$ & $-0.241 * * *$ \\
\hline South central & & $0.315 * * *$ & & $0.155 * * *$ & $0.179 * * *$ \\
\hline Southwest & & $\begin{array}{l}-0.610 * * * \\
(0.002)\end{array}$ & & $\begin{array}{l}-0.852 * * * \\
(0.002)\end{array}$ & $\begin{array}{l}-0.463 * * * \\
(.0002)\end{array}$ \\
\hline Southeast & & $1 * * *$ & & $8 * * *$ & $0.055 * * *$ \\
\hline Rural & & $(0.003)$ & $\frac{-1.040}{(0.001)} * * *$ & $\begin{array}{l}-.1074 * * * \\
(.0001)\end{array}$ & $9 * *$ \\
\hline & 0.09 & & 0.121 & 0.112 & \\
\hline & $11 ' 570,142$ & $11 ' 570,142$ & $11 ' 570,142$ & $11^{\prime} 763,574$ & $11^{\prime} 570,142$ \\
\hline
\end{tabular}

Notes: $* \mathrm{p}<0.05 ; * * \mathrm{p}<0.01 ; * * * \mathrm{p}<0.001$

Standard errors in parentheses.

Threshold values for each category in the dependent variable are omitted.

Source: 2015b, Intercensal Survey, Mexico, INEGI.

In accordance with what we found in the descriptive analysis, people self-identified as indigenous and indigenous language speakers are associated with lower propensities to have a higher level of education, 61.3 percent $(\exp (-0.950)-1)$ and 24.4 percent $(\exp (-0.279)-1)$ lower odds, res- 
pectively. This is particularly relevant for Afro-descendants who, as we saw previously, also self-identify as indigenous and of whom, ten percent identify as indigenous language speakers. We also find that the region of residence is a significant predictor of educational levels, compared to the Northwest, living in the Northeast, South Central, and Southeast regions is associated with increased levels of education, while living in the remaining regions is associated with lower levels of schooling. As it would be expected, rural residence is associated with lower levels of education (Table 5).

With regard to occupational status (Table 6), we also estimate a series of nested models. Model 1 includes individual characteristics, Model 2 adds educational attainment, Model 3 adds region of residence, Model 4 replaces region with rural residence, Model 5 is a full model except for indigenous characteristics, and Model 6 includes all covariates.

Model 1 finds that when accounting for individual characteristics only, Afro-Mexicans have higher likelihood of being in a higher status occupation, while indigenous self-identification and speaking an indigenous language are associated to lower status occupations. When we account for educational attainment in Model 2, these relationships change.

The effects of indigenous characteristics remain negative and significant, though they reduce in magnitude; while the effect of being Afro-Mexican reverses directions. And, as it would be expected, higher levels of educational attainment are consistently associated to improved occupational status.

Most of the aforementioned effects remain in Model three where we add controls for region of residence. However, the main difference is that the effect of identifying as Afro-descendant becomes positive again and increases in magnitude relative to the baseline effect in Model 1. In terms of region of residence, those living in the Northeast, Northcentral, South Central and Southeast regions of the country are more likely to be in higher status occupations, relative to those in the Northwest region, while living in the West, East, and Southwest is associated to lower status occupations. Further, when the effect of region is replaced by rural status in Model 4, the effect of African origin becomes negative again, whereas living in a rural community is associated to lower occupational status. In Model 5, we check if the effect of being Afro-descendant changes when we do not account for indigenous identification, and accounting for all the other covariates. We find that the effect of identifying as Afro-Mexican goes back to being positive. And the effects of region and rural status are consistent with the findings of Models 3 and 4. 
Table 6: Ordered logistic regression models predicting occupational status, ages 24 to 64, Mexico, 2015

\begin{tabular}{|c|c|c|c|c|c|c|}
\hline Independent Variables & Model 1 & Model 2 & Model 3 & Model 4 & Model 5 & Model 6 \\
\hline Afro-descendant & $\begin{array}{l}0.028+ \\
(0.005)\end{array}$ & & & $+\quad-0.028+$ & & \\
\hline Female & & + & & $+\quad-0.5$ & & \\
\hline Age & $\begin{array}{l}-0.019+ \\
(0.000)\end{array}$ & $\begin{array}{l}0.002 \\
(0.000)\end{array}$ & $\begin{array}{c}0.002 \\
(0.000)\end{array}$ & $+\begin{array}{c}0.000+ \\
(0.000)\end{array}$ & $\begin{array}{c}0.000+ \\
(0.000)\end{array}$ & $\begin{array}{c}0.001 \\
(0.000)\end{array}$ \\
\hline $\begin{array}{l}\text { Indigenous language } \\
\text { speaker }\end{array}$ & $-1.073+$ & $-0.718+$ & $-0.636+$ & $+\quad-0.572+$ & & $-0.5241+$ \\
\hline enous & $\begin{array}{l}(0.003) \\
-0.428+ \\
(0.002)\end{array}$ & $\begin{array}{l}(0.003) \\
-0.217+ \\
(0.002)\end{array}$ & $\begin{array}{l}(0.003) \\
-0.158+ \\
(0.002)\end{array}$ & $+\begin{array}{l}(0.003) \\
-0.144 \\
(0.002)\end{array}+$ & & $\begin{array}{l}(0.003) \\
-0.104+ \\
(0.002)\end{array}$ \\
\hline \multicolumn{7}{|c|}{ Education (ref. none to incomplete elementary) } \\
\hline $\mathrm{em}$ & & & $\begin{array}{l}0.473+ \\
(0.004)\end{array}$ & $+\begin{array}{c}0.487+ \\
(0.004)\end{array}$ & $\begin{array}{r}0 . \\
(0.0\end{array}$ & $\begin{aligned} 0 & \\
(0 . & .\end{aligned}$ \\
\hline Middle school & & $\begin{array}{l}1.2 \\
(0.00\end{array}$ & $\begin{array}{l}1.207+ \\
(0.004)\end{array}$ & $+\begin{array}{l}1.16 \\
(0.00\end{array}$ & $\begin{array}{l}1.2 \\
(0.00\end{array}$ & $\begin{array}{l}1.1 \\
(0.0\end{array}$ \\
\hline High school & & $\begin{array}{c}2.189+ \\
(0.004)\end{array}$ & $\begin{array}{l}2.103 \\
(0.004)\end{array}$ & $+\begin{array}{l}1.970+ \\
(0.004)\end{array}$ & $\begin{array}{l}2.040+ \\
(0.004)\end{array}$ & $\frac{1.922}{(0.004)}+$ \\
\hline $\begin{array}{l}\text { chnical } \\
\text { commercial degree }\end{array}$ & & & $3.094+$ & + $2.979+$ & $3.023+$ & $2.908+$ \\
\hline College degree & & $\begin{array}{c}(0.008) \\
4.418+ \\
(0.005)\end{array}$ & $\begin{array}{c}(0.008) \\
4.359+ \\
(0.005\end{array}$ & $+\begin{array}{c}(0.008) \\
4.198 \\
(0.005)\end{array}+$ & $\begin{array}{c}(0.0 \\
4.2 \\
0.0\end{array}$ & $\begin{array}{c}(0.008) \\
4.168+ \\
(0.005)\end{array}$ \\
\hline Postgraduate degree & & $\begin{array}{l}5.411+ \\
(0.007)\end{array}$ & $\begin{array}{c}5.332 \\
(0.007)\end{array}$ & $+\begin{array}{l}5.192 \\
(0.007)\end{array}+$ & $\begin{array}{l}5.258+ \\
(0.007)\end{array}$ & $\begin{array}{l}5.146+ \\
(0.007)\end{array}$ \\
\hline $\begin{array}{l}\text { Region (ref. Northwest) } \\
\text { Northeast }\end{array}$ & & & & & & \\
\hline West & & & $\begin{array}{l}(0.004) \\
-0.0420+\end{array}$ & & $\begin{array}{l}(0.004) \\
-0.043+ \\
0.003)\end{array}$ & $\begin{array}{l}(0.004) \\
-0.044+ \\
(0.003)\end{array}$ \\
\hline East & & & & & & \\
\hline North central & & & & & & $12+$ \\
\hline South central & & & & & & \\
\hline Southwest & & & & & & \\
\hline Southeast & & & & & & $0.191+$ \\
\hline Rural & & & & & $(0 \dot{0}$ & $(-0.943+$ \\
\hline $\begin{array}{l}\text { Pseudo R-Squared } \\
\mathrm{N}\end{array}$ & $\begin{array}{c}0.035 \\
5,323,428\end{array}$ & $\begin{array}{c}0.142 \\
5,313,139 \\
\end{array}$ & $\begin{array}{c}0.146 \\
5,313,139 \\
\end{array}$ & $\begin{array}{c}0.156 \\
9 \quad 5,313,139 \\
\end{array}$ & $\begin{array}{c}0.155 \\
5,416,907 \\
\end{array}$ & $\begin{array}{c}0.158 \\
5,313,139 \\
\end{array}$ \\
\hline
\end{tabular}

Note: $* \mathrm{p}<0.05 ; * * \mathrm{p}<0.01 ;+\mathrm{p}<0.001$

Standard errors in parentheses; Threshold values for each category in the dependent variable are omitted.

Source: 2015b, Intercensal Survey, Mexico, INEGI.

This set of models shows that the difference between those self-identified as Afro-descendant and those who are not are relatively small and vary in direction and magnitude depending on the covariates included in the model. The full model (Model 6) shows that Afro-descendants have 4.3 percent increased odds of being in a higher occupational status. Women 
have decreased odds (44.1 percent) to have higher occupational status, despite the fact that, as we saw in the previous models, they are more likely to attain higher education. Finally, indigenous language speakers and those who identify as indigenous are less likely ( 40.8 percent and ten percent lower odds, respectively) to attain higher occupational status. Education is positively associated to higher occupations, while region and rural residence follow a pattern similar to the models for educational attainment.

\section{Discussion}

In both the descriptive and the multivariate analyses, we found that Afro-descendant self-identification is associated with higher levels of education and better occupational status than expected. In the descriptive analysis we see that the Afro-descendant population has similar completed educational levels and occupational status as the rest of the population, whereas the main ethnic differentials we observe are for those who identify as indigenous. The multivariate analysis shows that Afro-descent identification is associated to higher levels of education ( 7.8 percent increased odds) and more modestly related to higher occupational status (4.3 percent increased odds) once we account for other characteristics.

Therefore, contrary to expectations and given the documented historical and current discrimination faced by this population, this study found no evidence that this population had a lower status in the labor market through occupational status, and even more remarkably in schooling. Why are these results contrary our expected findings?

First, results may be reflecting an issue of reverse causation. More educated people may be more likely to be - or to have become - aware of their ancestry and identity. At the same time, less educated people may have suffered more discrimination for being black or Afro-descendant, and thus prefer to not identify as such in an attempt to elude the stigma associated to this ethno-racial category. Likewise, people with lower education could have more limited knowledge of their origins, and as such, have lower afro-descent consciousness.

Second, our paper analyses Afro-descendant population in all of Mexico, but it is possible that a national-level analysis masks important sub-regional differences. In this sense, the concentration or dispersion of the Afro-descendant population in specific states or towns could result in different social dynamics which would result in a different distribution of socioeconomic status for Afro-descendants in each of them when compared to the rest of the population. 
Third, despite what we discussed in the two points above, the data is showing that while being an indigenous language speaker or identifying as indigenous in Mexico is associated to much lower socioeconomic attainment than for the rest of the population, these differences in socioeconomic achievement are not as pronounced for Afro-Mexicans relative to other Mexicans.

In any case, it is important to note that the results from our research do not attempt to deny that we can find Afro-descendant communities in Mexico who live in the poorest circumstances. Currently, an important proportion of the Afro-descendant population resides in regions of Mexico where poverty and extreme poverty are the norm, such as the states of Guerrero and Oaxaca (Conapred y Movimiento Nacional por la Diversidad Cultural de México, 2011). The top 100 municipalities with higher concentrations of Afro-descendant populations (ten percent and greater), where 227 thousand people identify as Afro-Mexican (not including those who self-identify as part Afro-descendant) show socioeconomic characteristics associated to worse living conditions than the national median (INEGI, 2017). Thus, it is important that future research considers the educational and occupational situation of Afro-descendants across different sub-national contexts.

Our objective with this preliminary investigation into new measures of racial identification in Census data is to contribute and to open the way for research examining both the consistency and reliability of the question on Afro-descendant identity, and to enhance our ability to study stratification in Mexico within this complex ethno-racial reality.

Given the emerging interest on the issue of Afro-descendants as well as the broader issue of skin color, it is likely that future Mexican surveys would include both a color palette and Afro-descendant self-identification questions, along with other relevant variables to better understand social stratification. If new data collection has a large enough sample of Afro-descendant population, future research could estimate the situation of Afro-descendants in the Mexican stratification system. In this paper we consider that the self-identification question in the Intercensal Survey are not only important to observe what is happening with identity, but to also study social stratification. It is possible that the social position of Afro-descendants can be explained by causes related to their ethnic identification (cultural factors) notwithstanding the importance of other explanatory variables such as skin color or parental occupation. 
One implication of our study is that prevailing expectations of the distribution of Afro-descendants in Mexico are more limited than reality. The study also raises important questions regarding the reliability of self-identification racial measures, and it makes us ask whether alternative methods of measurement would be more accurate. Future research should continue exploring the characteristics that determine Afro-descent identification in Mexico. Our analysis provides details on the characteristics and status attainment of this group and creates new avenues to consider exploring the make-up of this population in terms of other demographic characteristics.

\section{ReFERENCES}

Aguirre, G., 1946, 1972, La población negra de México: estudio etnohistórico, Fondo de Cultura Económica, Mexico.

Antón, J. and Popolo, F. del, 2009, "Visibilidad estadística de la población afrodescendiente de América Latina: aspectos conceptuales y metodológicos", in J. Antón, Á. Bello, F. del Popolo, M. Paixao and M. Rangel (eds), Afrodescendientes en América Latina y el Caribe: Del reconocimiento estadístico a la realización de derechos, CEPAL, Santiago de Chile.

Arceo-Gomez, E. and Campos-Vazquez, R. 2014, "Race and Marriage in the Labor Market: A Discrimination Correspondence Study in a Developing Country", American Economic Review, vol. 104, núm. 5.

CEPAL, 2017, "Situación de las personas afrodescendientes en América Latina y desafíos de políticas para la garantía de sus derechos", Naciones Unidas. Available: https://www.cepal.org/es/publicaciones/42654-situacion-personas-afrodescendientes-america-latina-desafios-politicas-la (accessed: May 2019)

Conapred and Movimiento Nacional por la Diversidad Cultural de México, 2011, Guía para la acción pública contra la discriminación y para la promoción de la igualdad e inclusión de la población afrodescendiente en México. Available: http://www.conapred.org.mx/userfiles/files/GAP-AFRO_2011_INACCSS.pdf (accessed: May 2019)

Cortés, F. and Escobar, A., 2005, "Movilidad social intergeneracional en el México urbano", Revista de la CEPAL, núm. 85.

Flores, R. and Telles, E., 2012, "Social Stratification in Mexico Disentangling Color, Ethnicity, and Class", American Sociological Review 77(3):486-494.

Flores, J. and Lézé, F., 2007, Procesos de construcción de identidad, condiciones de vida y discriminación: Un estudio comparativo de comunidades de los afrodescendientes en México. XXVI Congreso de la Asociación Latinoamericana de Sociología. Asociación Latinoamericana de Sociología, Guadalajara.

Gil, R., 2013, "The Mascogo/Black Seminole Diaspora: The Intertwining Borders of Citizenship, Race, and Ethnicity", Latin American and Caribbean Ethnic Studies, núm. 9, vol. 1:23-43. 
Hoffmann, O., 2008, “Entre etnización y racialización: los avatares de la identificación entre los afrodescendientes en México", in A. Castellanos (ed), Racismo e Identidades. Sudáfrica y Afrodescendientes en las Américas, UAM-Iztapalapa, México.

Hoffmann, O. and Rinaudo, C., 2014, "'The Issue of Blackness and Mestizaje in Two Distinct Mexican Contexts: Veracruz and Costa Chica", Latin American and Caribbean Ethnic Studies, vol. 9, núm. 2.

IDRE-UCLA, 2015, "Stata Data Analysis Examples Ordered Logistic Regression. Available: http://www.ats.ucla.edu/stat/stata/dae/ologit.htm (accessed: September 2016).

Instituto Nacional de Estadística y Geografía, 2015a, Encuesta Intercensal 2015. Síntesis metodológica y conceptual. Available: http://www.inegi.org.mx/est/contenidos/proyectos/encuestas/hogares/especiales/ei2015/doc/eic2015_sintesis.pdf (accessed September 2016.

Instituto Nacional de Estadística y Geografía, 2015b, "Microdatos Encuesta Intercensal 2015. Available: http://www3.inegi.org.mx/sistemas/microdatos/formato. aspx?c=34537 (accessed September 2016)

Instituto Nacional de Estadística y Geografía, 2015c, "Principales resultados de la Encuesta Intercensal 2015. Available: http://www.inegi.org.mx/est/contenidos/ proyectos/encuestas/hogares/especiales/ei2015/doc/eic2015_resultados.pdf (accessed: September 2016).

Instituto Nacional de Estadística y Geografía, 2017, Perfil Sociodemográfico de la Población Afrodescendiente en México, México.

Lewis, L., 2000, "Blacks, Black Indians, Afromexicans: The Dynamics of Race, Nation, and Identity in a Mexican Moreno Community (Guerrero)", American Ethnologist, vol. 27, núm. 4.

Martinez, R., Saldívar, E., Flores, R. and Sue, C., 2014, “The different Faces of Mestizaje. Ethnicity and Race in Mexico, in E. Telles (ed), Pigmentocracies: Ethnicity, Race, and Color in Latin America, The University of North Carolina Press, United States.

Ñopo, H., Chong, A. and Moro, A., 2010, "What Do We Know about Discrimination in Latin America? Very Little!" in H. Nopo, A. Chong and A. Moro (eds), Discrimination in Latin America: An Economic Perspective, Inter-American Development Bank - World Bank Publications, Washington D.C.

Popolo, F. del and Schkolnik, S., 2013, "Pueblos indígenas y afrodescendientes en los censos de población y vivienda de América Latina: avances y desafíos en el derecho a la información”, Notas de Población, núm. 97.

Sandoval, A. and Fernández, P., 2005, "Retorno al indigenismo existencialista", Demos 26-27.

Schkolnik, S., 2009, "La inclusión del enfoque étnico en los censos de población de América Latina“ Notas de Población, núm. 89. 
Solis, P., 2002, Structural Change and Men's Work Lives: Transformations in Social Stratification and Occupational Mobility in Monterrey, Mexico, Ph.D. dissertation, The University of Texas at Austin, Austin, TX.

Sue, C., 2013, Land of the cosmic race: Race mixture, racism, and blackness in Mexico, Oxford University Press, Oxford.

Telles, E. and Ortiz, V., 2008, Generaciones excluidas: mexicano-estadounidenses, asimilación y raza, Centro de Investigaciones Sociológicas, Madrid.

Telles, E., 2014, Pigmentocracies: Ethnicity, Race, and Color in Latin America, The University of North Carolina Press, United States.

Telles, E. and Paixao, M., 2013, Affirmative Action in Brazil, LASA Forum 44.

Telles, E., Flores, R. and Urrea-Giraldo, F., 2015, "Pigmentocracies: Educational inequality, skin colour and census ethnoracial identification in eight Latin American countries", Research in Social Stratification and Mobility, núm. 40.

Torre Cantalapiedra, E., 2018, "Racial Mixing and National Integration in Latin America. The Return of Racial Differences in Mexico and Brazil", Latin American Perspectives, vol. 45, núm. 2.

Torre Cantalapiedra, E., 2017, "Novedades en el panorama de las identidades en México: la pregunta sobre afrodescendientes en la Encuesta Intercensal, 2015", Coyuntura Demográfica, núm. 12. Available: http://www.somede.org/coyuntura-demografica/index.php/numero-12/item/novedades-panorama-identidades-mexico-pregunta-sobre-afrodescendientes-encuesta-intercensal-2015 (accessed: May 2019)

Urrea-Giraldo, F. 2006. La población afrodescendiente en Colombia. Pueblos indígenas y afrodescendientes de América Latina y el Caribe: información sociodemográfica para políticas y programas, Project documents, № 72 (LC/W.72). Santiago de Chile: Comisión Económica para América Latina y el Caribe (CEPAL).

Velázquez, M. and Iturralde, G., 2012, Afrodescendientes en México. Una historia de silencio y discriminación, CONAPRED/CONACULTA, México.

Villarreal, A., 2010, "Stratification by skin color in contemporary Mexico", American Sociological Review, vol. 75, núm. 5.

Zenteno, R. and Solís, P., 2006, "Continuidades y discontinuidades de la movilidad ocupacional en México“ Estudios Demográficos y Urbanos, vol. 2, núm. 3.

\section{RESUMEN CURRICULAR DE LOS AUTORES}

\section{Eduardo Torre Cantalapiedra}

Maestro en Relaciones Económicas Internacionales y Cooperación por la Universidad de Guadalajara y Doctor en Estudios de Población por el El Colegio de México. Ha sido investigador posdoctoral e impartido docencia en la Universidad Nacional Autónoma de México. Actualmente es investigador Cátedras Conacyt - El Colegio de la Frontera Norte. Pertenece 
al Sistema Nacional de Investigadores (Nivel 1). Entre sus publicaciones recientes destacan Diario de Campo, vol. 2, 2019; "Migración, racismo y xenofobia en Internet: análisis del discurso contra los migrantes haitianos de usuarios en prensa digital mexicana", Revista Pueblos y Fronteras Digital, vol. 14, 2019 y "Racial Mixing and National Integration in Latin America. The Return of Racial Differences in Mexico and Brazil", Latin American Perspectives, vol. 45, 2018.

Dirección electrónica: eduardotorrephd@gmail.com

\section{Gabriela Sánchez Soto}

Maestra y Doctora en Sociología por la Universidad de Brown. Ha sido investigadora posdoctoral de la Oficina de Estudios de Población de la Universidad de Princeton (2011-2012) y profesora de Demografía en La Universidad de Texas en San Antonio (2012-2019). Actualmente es investigadora visitante en el Centro de Estudios México-Americanos de la Universidad de Houston. Entre sus publicaciones recientes destacan: The Return-On-Education Gap between Hispanics and Non-Hispanic Whites in the U.S. (en co-autoría con Andrea Bautista León y Joachim Singelmann, The Occupational Mobility of Mexican Migrants in the United States (en co-autoría con Joachim Singelmann) y En búsqueda de su camino. Características de los jóvenes que no estudian ni trabajan en la Ciudad de México (en coautoría con Andrea Bautista León).

Dirección electrónica: gsanchez-soto@uh.edu 